\title{
Salacia chinensis L. Stem Extract Exerts Antifibrotic Effects on Human Hepatic Stellate Cells through the Inhibition of the TGF- $\beta 1$-Induced SMAD2/3 Signaling Pathway
}

\author{
Mattareeyapar Phaosri ${ }^{1,2}$ D, Salinee Jantrapirom ${ }^{1}\left(\mathbb{D}\right.$, Mingkwan Na Takuathung $^{1,3}$ (D), $^{-}$ \\ Noppamas Soonthornchareonnon ${ }^{4}$, Seewaboon Sireeratawong ${ }^{1}$ (D), Pensiri Buacheen ${ }^{2,5}$, \\ Pornsiri Pitchakarn ${ }^{5}$ (D) Wutigri Nimlamool ${ }^{1,3}$ and Saranyapin Potikanond $1,3, *$ (D) \\ 1 Department of Pharmacology, Faculty of Medicine, Chiang Mai University, Chiang Mai 50200, \\ Thailand; mattareeyapar@gmail.com (M.P.); salinee.jan@cmu.ac.th (S.J.); mingkwan.n@cmu.ac.th (M.N.T.); \\ seewaboon@gmail.com (S.S.); wutigri.nimlamool@cmu.ac.th (W.N.) \\ 2 Graduate School, Chiang Mai University, Chiang Mai 50200, Thailand; pensiri8@hotmail.com \\ 3 Research Center of Pharmaceutical Nanotechnology, Chiang Mai University, Chiang Mai 50200, Thailand \\ 4 Department of Pharmacognosy, Faculty of Pharmacy, Mahidol University, Thung Phaya Thai, \\ Rajathevi, Bangkok 10400, Thailand; noppamas.sup@mahidol.ac.th \\ 5 Department of Biochemistry, Faculty of Medicine, Chiang Mai University, Chiang Mai 50200, \\ Thailand; pornsiri.p@cmu.ac.th \\ * Correspondence: saranyapin.p@cmu.ac.th or spotikanond@gmail.com
}

Received: 14 November 2019; Accepted: 12 December 2019; Published: 13 December 2019

\begin{abstract}
Salacia chinensis L. (SC) stems have been used as an ingredient in Thai traditional medicine for treating patients with hepatic fibrosis and liver cirrhosis. However, there is no scientific evidence supporting the antifibrotic effects of SC extract. Therefore, this study aimed to determine the antifibrotic activity of SC stem extract in human hepatic stellate cell-line called LX-2. We found that upon TGF- $\beta 1$ stimulation, LX-2 cells transformed to a myofibroblast-like phenotype with a noticeable increase in $\alpha$-SMA and collagen type I production. Interestingly, cells treated with SC extract significantly suppressed $\alpha$-SMA and collagen type I production and reversed the myofibroblast-like characteristics back to normal. Additionally, TGF- $\beta 1$ also influenced the development of fibrogenesis by upregulation of MMP-2, TIMP-1, and TIMP-2 and related cellular signaling, such as pSmad2/3, pErk1/2, and pJNK. Surprisingly, SC possesses antifibrotic activity through the suppression of TGF- $\beta 1$-mediated production of collagen type 1, $\alpha$-SMA, and the phosphorylation status of Smad2/3, Erk1/2, and JNK. Taken together, the present study provides accumulated information demonstrating the antifibrotic effects of SC stem extract and revealing its potential for development for hepatic fibrosis patients.
\end{abstract}

Keywords: Salacia chinensis L.; hepatic fibrosis; hepatic stellate cells; LX-2 cells; transforming growth factor-beta 1

\section{Introduction}

The development of hepatic fibrosis is based on an alteration in balanced processes between extracellular matrix (ECM) production and degradation [1]. The primary effector cells that are a key for hepatic fibrogenesis are hepatic stellate cells (HSCs) [2,3]. Normally, HSCs in a quiescent stage produce low level of alpha-smooth muscle actin ( $\alpha$-SMA) and collagen, the markers for fibrosis [4]. In response to liver damage, a variety of paracrine factors, especially transforming growth factor-beta1 (TGF- $\beta 1$ ), activate HSC proliferation and transformation into myofibroblast-like cells, which produces 
excessive amounts of ECM, including collagens (especially types I, III, and V), elastin, glycoproteins, proteoglycans, and hyaluronan [2,5]. The activation of HSCs that increases the ECM remodeling task is a natural process for wound healing in liver tissue [6]. After the injury has subsided, the tissues turn back to the resolution stage, and HSCs become inactive. However, if the damage continues to occur, fibrogenesis is gradually built up and leads to hepatic fibrosis and eventually liver cirrhosis [1]. An increase in ECM accumulation and a decrease in matrix degradation result in the progression of hepatic fibrosis [7].

The role of HSCs to degrade ECM is dependent on matrix metalloprotease (MMP) production [8]. The expressions of MMP-2 (known as gelatinase-A) and MMP-9 (known as gelatinase-B) are significantly upregulated in liver fibrosis for ECM remodeling [9]. During HSCs activation and before increased collagen type I expression, HSCs produce the physiological tissue inhibitors of the MMPs (TIMPs), particularly TIMP-1 and TIMP-2 [10]. Particularly, TIMP-1 production is enhanced upon stimulation through TGF- $\beta 1$ signaling pathway, which is mediated by the activation of TGF- $\beta$ receptor and the activation of the major downstream molecules (SMAD2/3 phosphorylation) [11,12]. Previous studies have demonstrated that inhibition of the TGF- $\beta 1$ signaling pathway attenuates liver fibrosis [12-14]. In addition, the mitogen activated protein kinases (MAPK) family, including the three major subgroups (extracellular signal-regulated kinase (ERK), p38, and c-Jun N-terminal kinase/stress-activated protein kinase (JNK)), are involved in the proliferation and activation of HSCs and the aggravation of hepatic fibrosis [15]. Interestingly, the prevention of proliferation and migration of HSCs may be key strategies to reduce the progression of hepatic fibrosis $[16,17]$. However, there is no standard treatment for hepatic fibrosis. Recently, drug discovery for fibrosis treatment is focusing on interfering with TGF- $\beta$ signaling to reduce hepatic inflammation, inhibit stellate cell activation, and stimulate matrix degradation $[6,18]$.

Alternative medicine has emerged as an interesting means for treating hepatic fibrosis. The water extract of Salacia chinensis L. (SC) stem or 'Kumpang jed chan' in Thai has been used as a folk remedy to treat patients with cirrhosis in a local hospital with promising results. All parts of this plant contain many biologically active compounds, such as triterpenes, phenolic compounds, flavonoids, glycosides, condensed tannin, steroids, xanthone glucoside, and mangiferin [19-22], which show diverse medicinal properties, including antioxidant, hypoglycemic, and antiobesity activity [21,23,24]. Although promising results of SC stem water extract have been demonstrated in hepatic fibrotic patients, there is no scientific evidence revealing the effects of SC stem water extract on hepatic fibrosis thus far.

Therefore, this study aimed to determine antifibrotic activities of SC stem extract and its possible mechanisms of action. The human HSC cell line, LX-2, was used to explore the antifibrotic effects of SC stem extract upon TGF- $\beta 1$ activation by observing several markers, including $\alpha$-SMA and collagen type I production, the regulation and activity of MMP-9, MMP-2, TIMP-1, and TIMP-2, and multiple signaling transduction pathways, including SMAD2/3 and MAPK.

\section{Results}

\subsection{Salacia chinensis L. (SC) Stem Extract Reverses Morphology of HSCs Activation and Suppresses Its Migration via TGF- $\beta 1$}

The extraction of Salacia chinensis L. (SC) stem provided yield of SC extract at $7.35 \% \mathrm{w} / \mathrm{w}$. To establish the HPLC fingerprint chromatogram for quality control of the SC stem extract, five phenolic acids were quantitatively analyzed. The results found that the SC extract contained at least gallic acid $(0.38 \pm 0.007 \mathrm{mg} / \mathrm{g}$ extract) , as seen in Supplementary Figure S1.

HSC activation is one of the critical processes during hepatic fibrosis. LX-2 cells, which are characterized as an HSC cell line, have been used in this study. Firstly, the cytotoxicity of SC extract in the concentration range of $0-0.1 \mathrm{mg} / \mathrm{mL}$ was determined by a colorimetric MTT assay. After $48 \mathrm{~h}$ incubation, all concentrations of SC stem extract were not toxic to the cells, as seen in Figure 1A. We selected three concentrations of SC stem extract $(0.01,0.05$, and $0.1 \mathrm{mg} / \mathrm{mL})$ for further investigation. Our initial investigation explored whether SC stem extract suppresses activated HSC transformation 
in response to TGF- $\beta 1$ stimulation. The schematic is shown in Figure 1B. Normally, LX-2 cells without TGF- $\beta 1$ stimulation (UT) show the characteristics of unactivated primary HSCs, as seen in Figure 1C. In contrast, when TGF- $\beta 1$ at $2 \mathrm{ng} / \mathrm{mL}$ was added to the cells and incubated for $24 \mathrm{~h}$, the cells strongly exhibited the activated form of HSCs, as seen in Figure 1C. Specifically, TGF- $\beta 1$-stimulated HSCs showed morphological changes recognized as myofibroblasts with remarkable cellular structure reorganization, including clumping, stretching, and generating many obvious cell-free areas, as seen in Figure 1C. Interestingly, after $48 \mathrm{~h} \mathrm{SC}$ stem extract treatment, we noticed dramatic changes in cell morphology and cell-cell contact reorganization in a concentration-dependent manner, as seen in Figure 1C. These observations were clearly seen when the concentration of SC extract was increased. In particular, cells treated with SC extract at $0.1 \mathrm{mg} / \mathrm{mL}$ exhibited the overall characteristics of untreated cells, as seen in Figure 1C.

HSC migration has been identified as an initial process which causes hepatic tissue remodeling and fibrotic progression [25]. We identified the effect of SC stem extract on HSCs migration by observing its ability to inhibit the wound healing process. The effect of SC suppression of HSC migration was clearly observed $48 \mathrm{~h}$ after the treatment in a concentration-dependent manner. The highest SC concentration at $0.1 \mathrm{mg} / \mathrm{mL}$ revealed nearly $75 \%$ suppression compared to the untreated cells, as seen in Figure 2A,B.

A

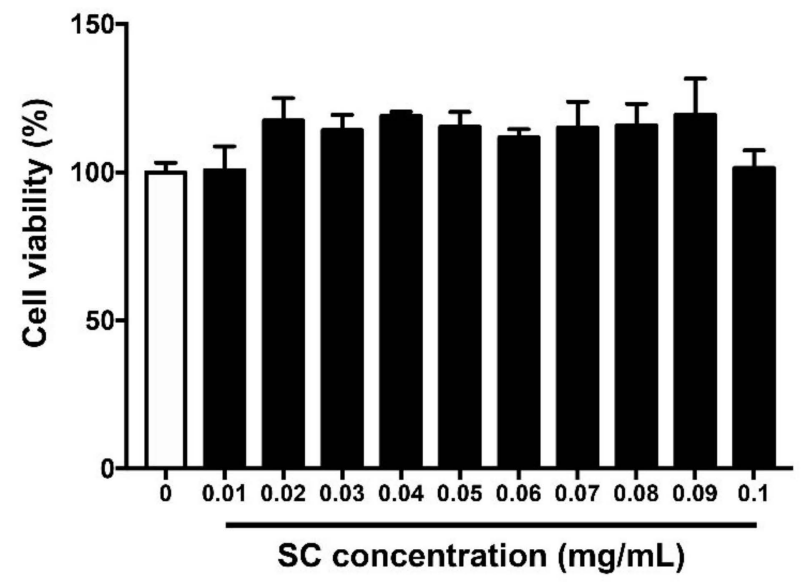

B

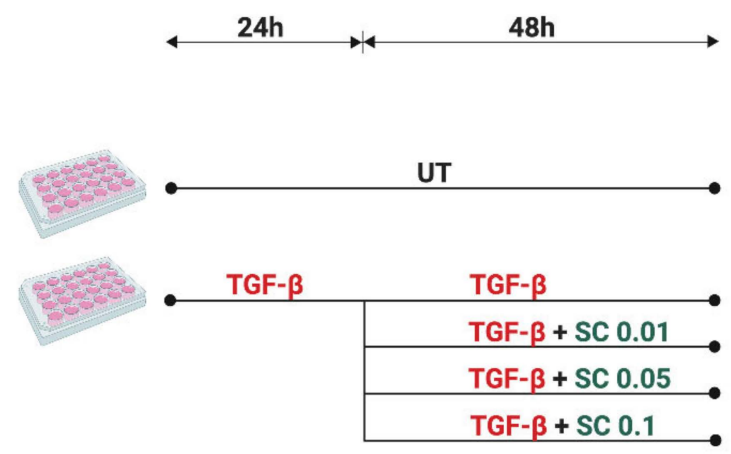

Figure 1. Cont. 
C
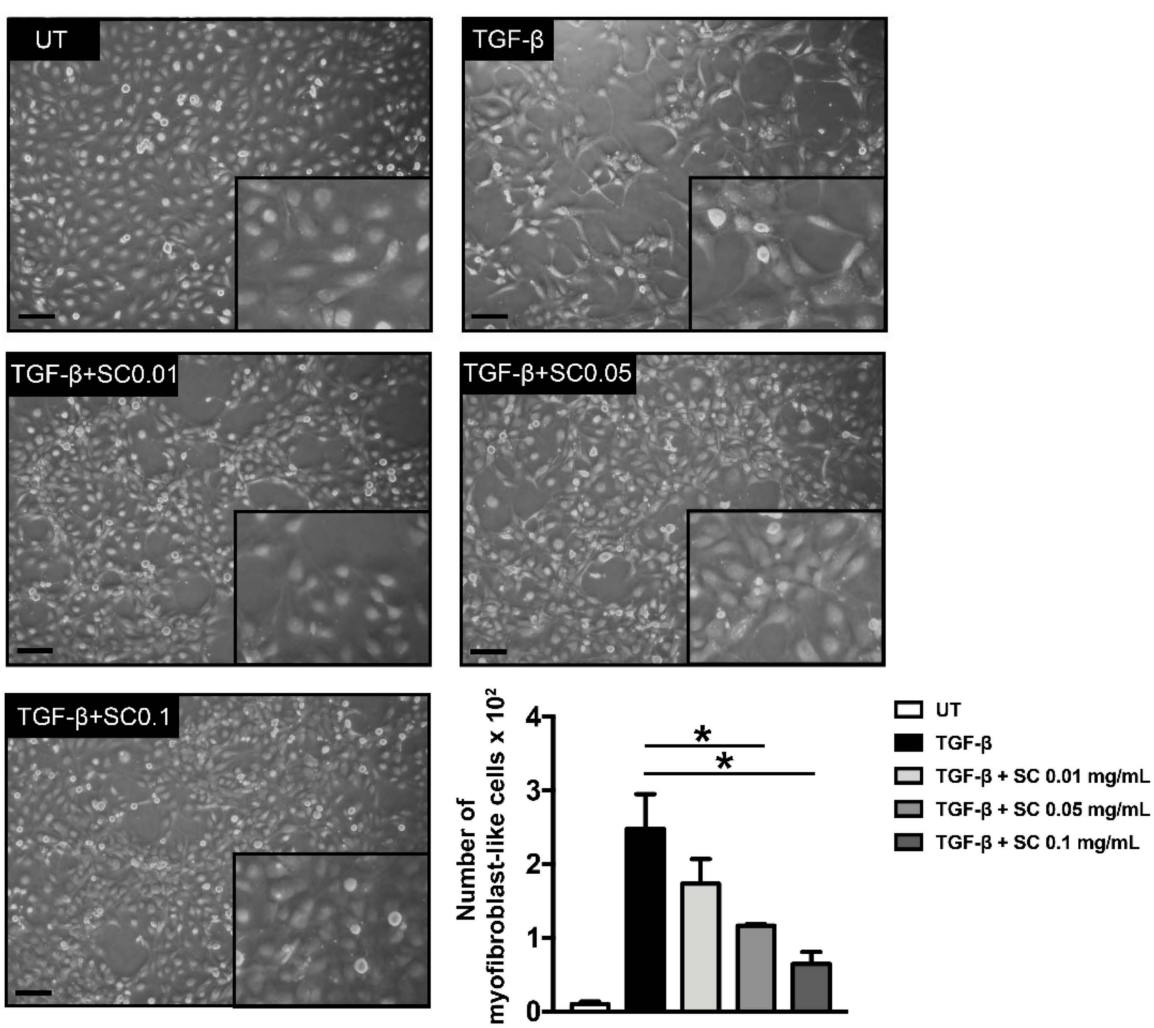

Figure 1. Effects of SC stem extract on stimulated hepatic stellate cell (HSC) morphology. Cell viability of LX-2 cells after SC treatments at 0.01 to $0.1 \mathrm{mg} / \mathrm{mL}$ are shown in (A). A schematic diagram of the experimental design is shown in (B). LX-2 morphology observed under a phase contrast microscopy is shown in (C). UT: untreated; TGF- $\beta$ : TGF- $\beta 12 \mathrm{ng} / \mathrm{mL}$; SC: Salacia chinensis L. extract. Scale bar $=50 \mu \mathrm{m}$. * $p<0.05$.

A

Oh

$24 h$

48h

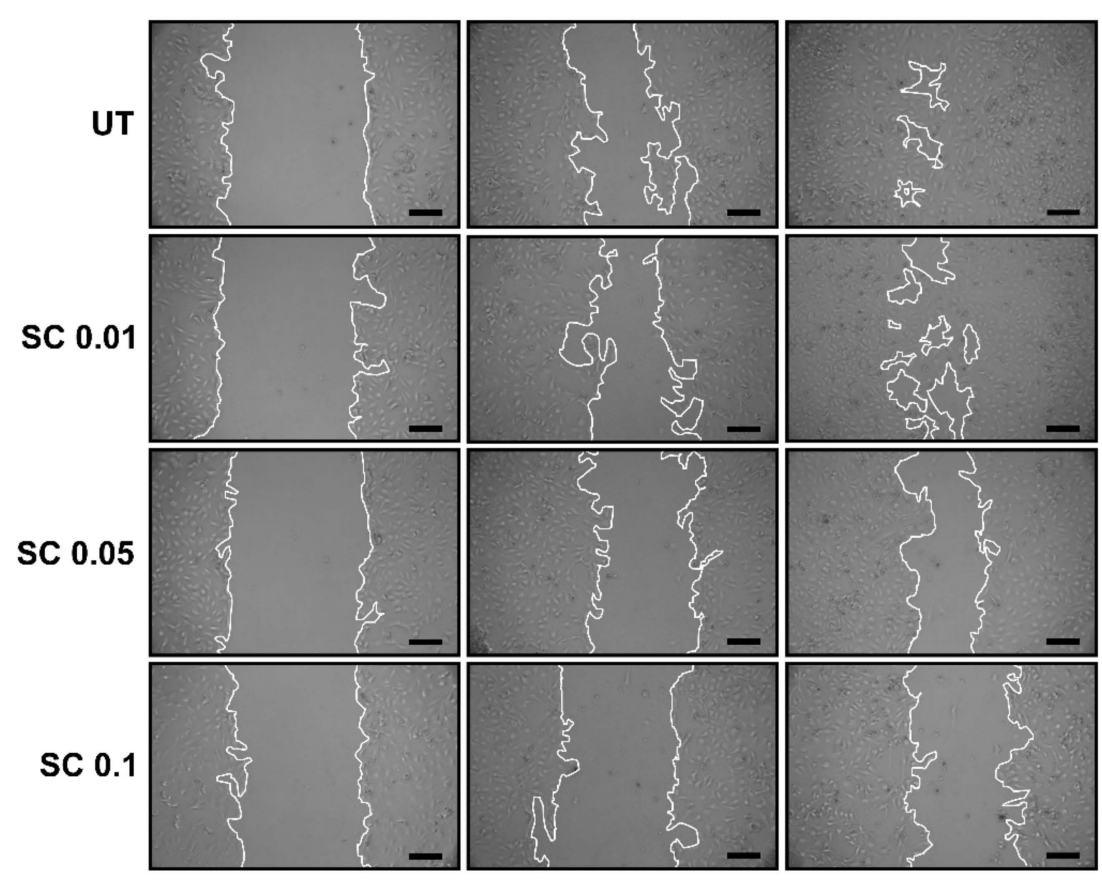

Figure 2. Cont. 
B

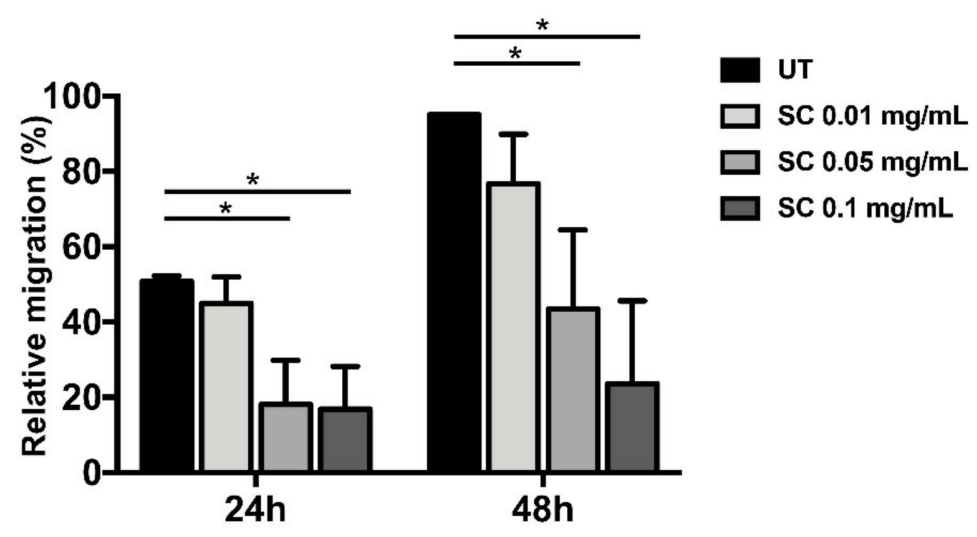

Figure 2. Effects of SC stem extract on HSC 2D migration. Cell migration was observed at $0 \mathrm{~h}, 24 \mathrm{~h}$, and $48 \mathrm{~h}$ after SC treatments (A). The percentage of cell migration at $24 \mathrm{~h}$ and $48 \mathrm{~h}$ after SC treatments is quantified in (B). UT: untreated; SC: Salacia chinensis L. extract. Scale bar $=50 \mu \mathrm{m} .{ }^{*} p<0.05$.

\subsection{Salacia chinensis L. (SC) Stem Extract Suppresses Fibrotic Markers at the Gene Expression Level}

Based on the observation that SC extract suppresses HSCs migration and can prevent TGF- $\beta 1$-induced fibrotic-related morphological changes, we hypothesized that the extract may also have the ability to suppress important fibrotic markers at the gene expression level. To test our hypothesis, the mRNA expression level of $\alpha$-SMA, COL1A1, MMP-2, MMP-9, TIMP-1, and TGF- $\beta 1$ was determined by qRT-PCR using GAPDH as an internal control. The normal HSCs expressed very low levels of all fibrotic-related genes. After incubation for $24 \mathrm{~h}$ with $2 \mathrm{ng} / \mathrm{mL}$ TGF- $\beta 1$, the expression of all selected genes was undoubtedly increased, as seen in Figure $3 \mathrm{~A}-\mathrm{F}$, compared to untreated cells. Interestingly, the extract at all concentrations could suppress the expression of all selected genes, except $M M P-9$, as seen in Figure 3A-F. These results suggest that SC stem extract initially suppresses fibrotic markers at the transcriptional level.

A

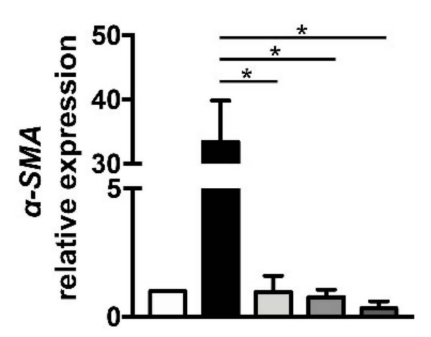

C

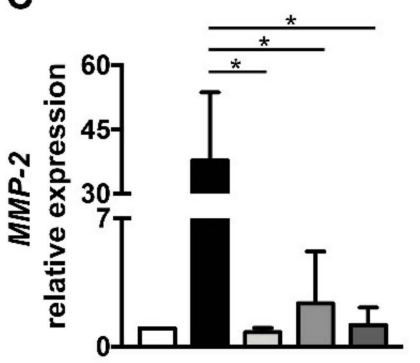

B

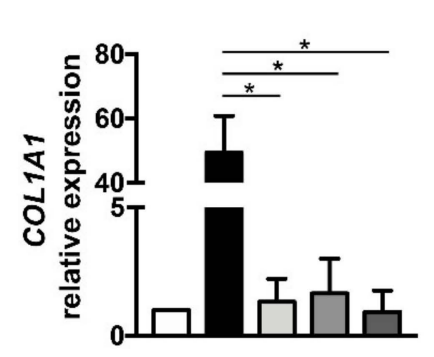

D

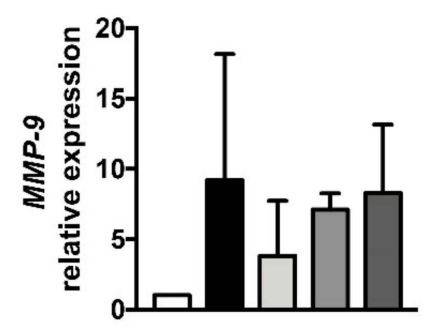

Figure 3. Cont.

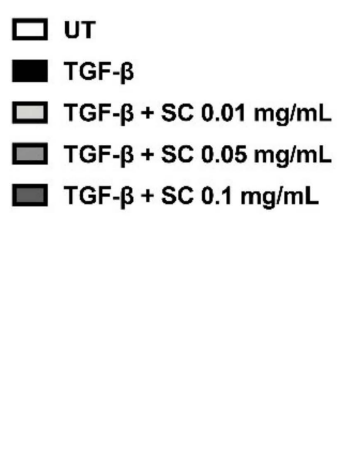


E

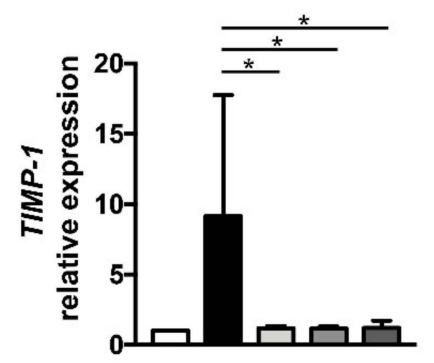

$\mathbf{F}$

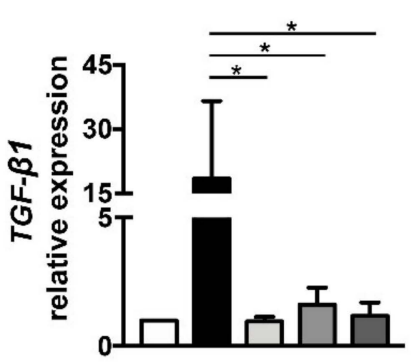

Figure 3. Effects of SC stem extract on mRNA expressions. The mRNA expression of (A) $\alpha-S M A$, (B) COL1A1, (C) MMP-2, (D) MMP-9, (E) TIMP-1, and (F) TGF- $\beta 1$ was measured by quantitative RT-PCR. GAPDH was used as an internal control. UT: untreated; TGF- $\beta$ : TGF- $\beta 12 \mathrm{ng} / \mathrm{mL}$; SC: Salacia chinensis L. extract. ${ }^{*} p<0.05$ indicates statistical significance from TGF- $\beta 1$-treated group.

\subsection{Translational Levels of Fibrotic Markers Are Suppressed by Salacia chinensis L. (SC) Stem Extract}

Since we observed the reduction of major fibrotic-related gene expression, including $\alpha-S M A$ and COL1A1 after SC treatment, we further investigated the existence of these two proteins by immunofluorescence study and confirmed the protein levels by western blot analysis. In untreated cells, $\alpha$-SMA and COL1A1 proteins were produced at low levels and $\alpha$-SMA, especially, was observed as a diffused signal in the cytoplasm of the cells, as seen in Figure 4A. TGF- $\beta 1$ prominently induced both $\alpha$-SMA and collagen production, as shown in Figure 4A. In addition, the increment of $\alpha$-SMA in TGF- $\beta 1$ treated cells was likely transformed from diffused forms to fibrillar structures, as seen in Figure 4A. As expected, the individual cells with SC treatment had a decreased intensity of $\alpha$-SMA and COL1A1 signals, as seen in Figure 4A. Western blot analysis also confirmed that SC stem extract could dramatically reduce TGF- $\beta 1$-stimulated production of $\alpha$-SMA as well as COL1A1 levels, as seen in Figure $4 B, C$, in a concentration-dependent manner.

A

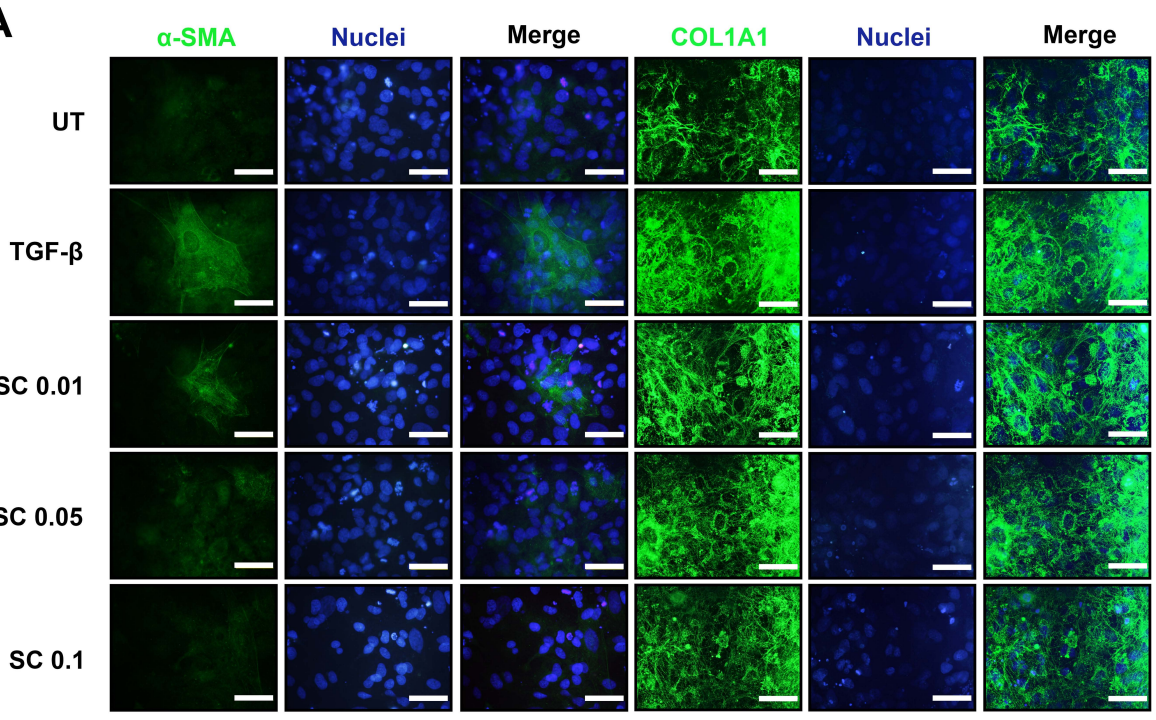

Figure 4. Cont. 
B

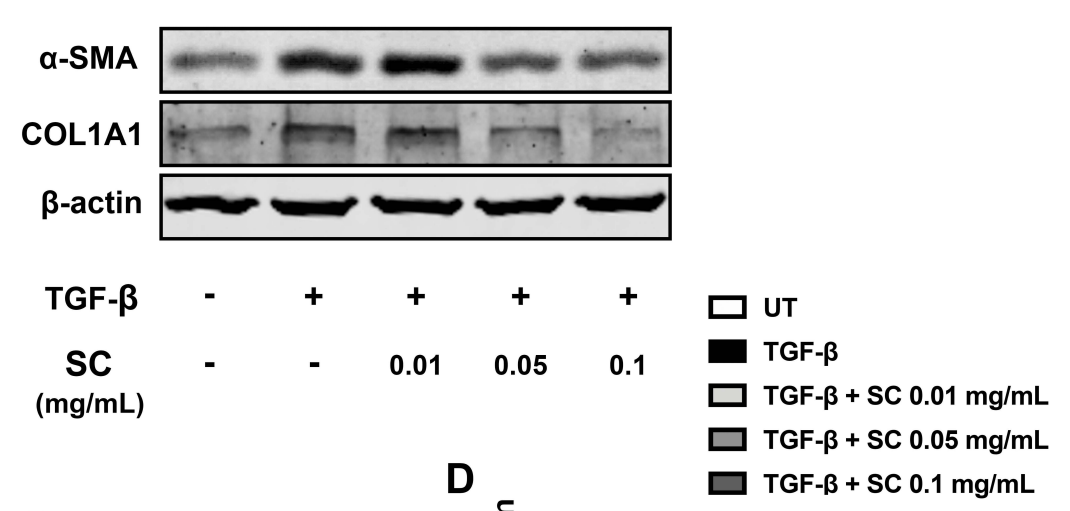

C

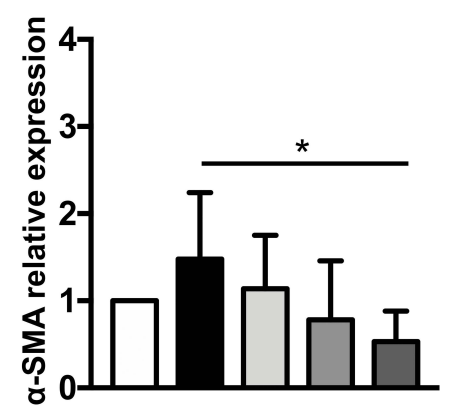

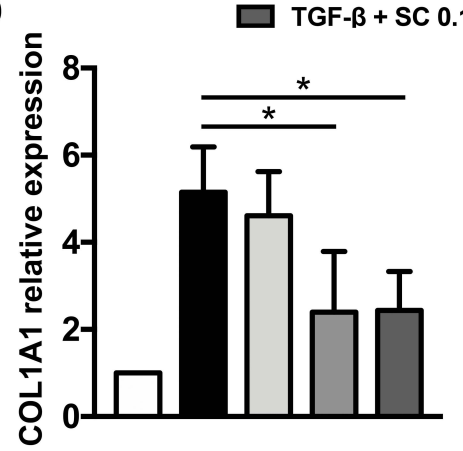

Figure 4. Effects of SC stem extract on $\alpha$-SMA and collagen type I production. Both $\alpha$-SMA and COL1A1 protein expression (Green) were examined by immunofluorescent staining (A). The nuclei (Blue) were stained with Hoechst 33342. The quantitative protein production of $\alpha$-SMA and collagen type I (COL1A1) (B) was measured by western blotting. The bar graphs represent the relative expression of these proteins after normalization to $\beta$-actin (C,D). UT: untreated; TGF- $\beta$ : TGF- $\beta 12 \mathrm{ng} / \mathrm{mL}$; SC: Salacia chinensis L. extract. ${ }^{*} p<0.05$ indicates statistical significance from the TGF- $\beta 1$-treated group. Scale bar $=200 \mathrm{um}$.

\subsection{Salacia Chinensis L. (SC) Stem Extract Reduced ECM Components}

Since dysregulation of extracellular matrix (ECM) components is an important factor in hepatic fibrotic progression, we investigated the effects of SC stem extract on the balance of major ECMs. In particular, the level of MMP-2 has been reported to be increased in liver fibrosis [26,27]. This report was supported by our finding that the expression of the MMP-2 gene was tremendously increased in response to TGF- $\beta 1$ stimulation, as seen in Figure $3 C$. According to our observation that the extract at all concentrations could effectively reduce MMP-2 expression, as seen in Figure 5A,C, we therefore performed gelatin zymography to verify whether the activity of MMP-2 is also decreased in SC stem extract-treated cells. Undoubtedly, the results showed that the extract could be able to reduce the activity of MMP-2 compared to that of TGF- $\beta 1$-treated cells, and this observation is seen in a concentration-dependent manner, as seen in Figure 5A,C. Specifically, TGF- $\beta 1$ increased the activity of MMP-9 compared to that of the untreated cells, whereas the extract at all concentrations additionally increased the TGF- $\beta 1$-induced MMP-9 activity, suggesting an ability of SC extract to increase MMP-9 activity, as seen in Figure 5A,B. Moreover, we further investigated whether the activity of both MMP-2 and MMP-9 is affected by their protein production level by performing western blot analysis to evaluate the existence of MMP-2 and MMP-9. As expected, MMP-9 protein was reduced in SC extract treated cells, as seen in Figure 5F,G, whereas MMP-2 protein was increased, as seen in Figure 5F,H. The major proteins that regulate the function of MMP-2 and MMP-9 are TIMP-1 and TIMP-2, which are profibrotic factors in the liver, and they have the ability to enhance fibrotic processes without affecting collagen synthesis. We wonder whether TIMP-1 and TIMP-2 levels could be affected by changes in MMP-2 and MMP-9 activity. After TGF- $\beta 1$ stimulation, we observed the increase of TIMP- 1 and TIMP-2 protein levels and the extract significantly reduced both TIMP-1 and TIMP-2 protein levels in 
a concentration-dependent manner, as seen in Figure 5A,D,E. However, the ratios of MMP-1:TIMP-1 and MMP-9:TIMP-1 in SC-treated cells at $0.1 \mathrm{mg} / \mathrm{mL}$ were increased, as seen in Table 1 . This result indicated that the majority of MMP-1 and MMP-9 were not inhibited, with consequently enhanced collagen degradation.

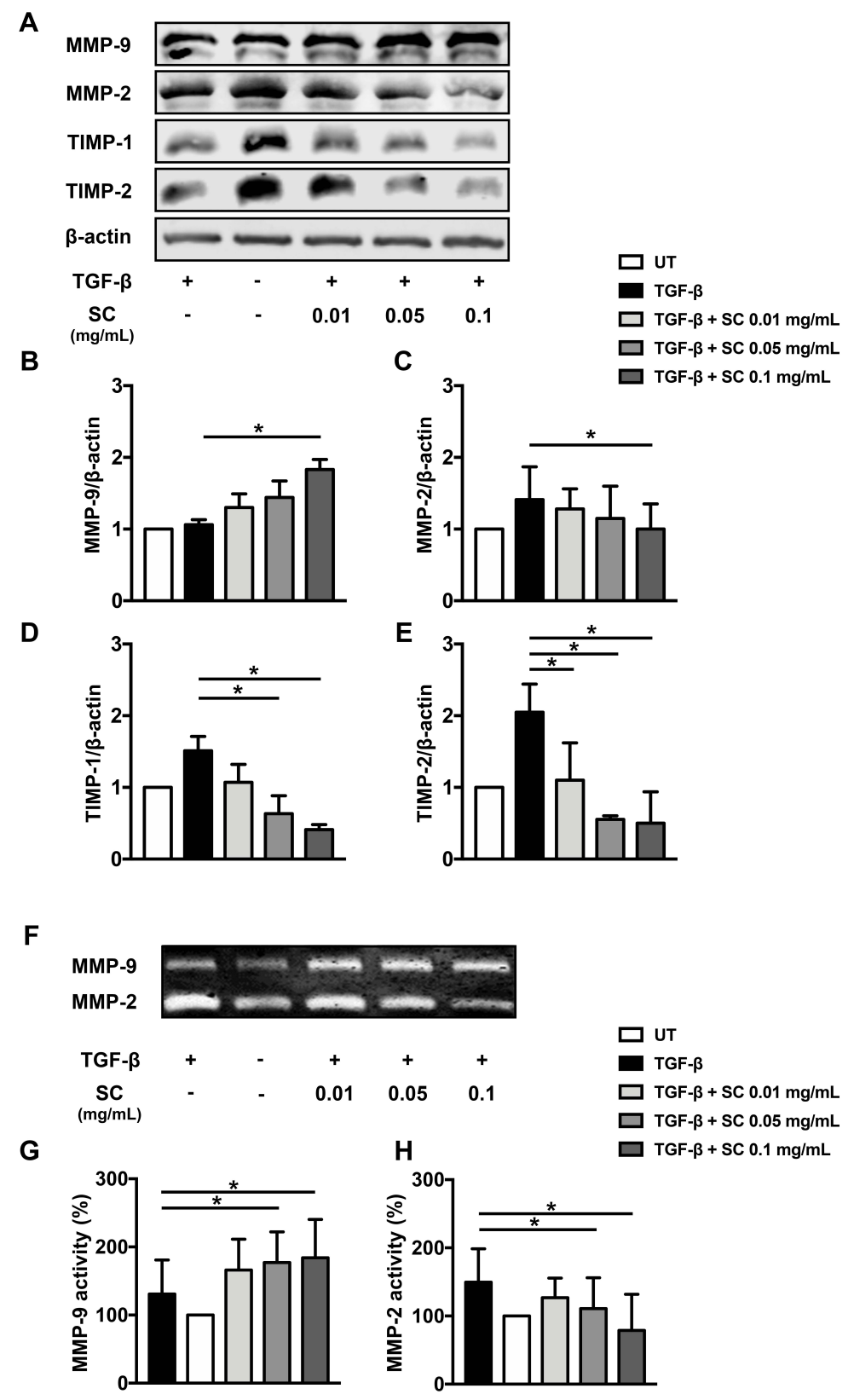

Figure 5. Effects of SC stem extract on secreted extracellular matrix components. Western blot analysis of MMP-9, MMP-2, TIMP-1, and TIMP-2 protein expressions in supernatant of LX-2 cells was shown (A). The bar graphs represent the relative protein expressions of MMP-9 (B), MMP-2 (C), TIMP-1 (D), and TIMP-2 (E) after normalization to $\beta$-actin. MMP-2 and MMP-9 activity was investigated by gelatin zymography (F) and the bar graphs represent the percentage of relative MMP-9 (G) and MMP-2 (H) activities. UT: untreated; TGF- $\beta$ : TGF- $\beta 12 \mathrm{ng} / \mathrm{mL}$; SC: Salacia chinensis L. extract. ${ }^{*} p<0.05$ indicates statistical significance from TGF- $\beta 1$-treated group. 
Table 1. Fold change of protein production (MMP-1, MMP-2, and MMP-9) and the ratio of production.

\begin{tabular}{|c|c|c|c|c|c|c|c|c|}
\hline \multirow{2}{*}{ Groups } & \multicolumn{5}{|c|}{ Fold Change of Protein Production } & \multicolumn{3}{|c|}{ Ratio of Production } \\
\hline & MMP-1 & MMP-2 & MMP-9 & TIMP-1 & TIMP-2 & $\frac{M M P-1}{T I M P-1}$ & $\frac{M M P-2}{T I M P-2}$ & $\frac{M M P-9}{T I M P-1}$ \\
\hline UT & $\begin{array}{c}1.00 \pm \\
0.00\end{array}$ & $\begin{array}{c}1.00 \pm \\
0.00\end{array}$ & $\begin{array}{c}1.00 \pm \\
0.00\end{array}$ & $\begin{array}{c}1.00 \pm \\
0.00\end{array}$ & $\begin{array}{c}1.00 \pm \\
0.00\end{array}$ & 1 & 1 & 1 \\
\hline TGF- $\beta$ & $\begin{array}{c}1.20 \pm \\
0.08\end{array}$ & $\begin{array}{c}1.41 \pm \\
0.46\end{array}$ & $\begin{array}{c}0.96 \pm \\
0.07\end{array}$ & $1.5 \pm 0.20$ & $\begin{array}{c}2.05 \pm \\
0.39\end{array}$ & 0.80 & 0.69 & 0.64 \\
\hline $\begin{array}{c}\text { TGF- } \beta+ \\
\text { SC0.01 }\end{array}$ & $\begin{array}{c}1.20 \pm \\
0.01\end{array}$ & $\begin{array}{c}1.28 \pm \\
0.28\end{array}$ & $\begin{array}{c}1.30 \pm \\
0.19\end{array}$ & $\begin{array}{c}1.07 \pm \\
0.25\end{array}$ & $\begin{array}{c}1.10 \pm \\
0.52\end{array}$ & 0.63 & 0.62 & 1.27 \\
\hline $\begin{array}{c}\text { TGF- } \beta+ \\
\text { SC0.05 }\end{array}$ & $\begin{array}{c}1.17 \pm \\
0.13\end{array}$ & $\begin{array}{c}1.15 \pm \\
0.45\end{array}$ & $\begin{array}{c}1.44 \pm \\
0.23\end{array}$ & $\begin{array}{c}0.63 \pm \\
0.25\end{array}$ & $\begin{array}{c}0.55 \pm \\
0.05\end{array}$ & 1.85 * & 2.08 & 2.29 \\
\hline $\begin{array}{c}\text { TGF- } \beta+ \\
\text { SC0.1 }\end{array}$ & $\begin{array}{c}0.77 \pm \\
0.07\end{array}$ & $\begin{array}{c}1.00 \pm \\
0.35\end{array}$ & $\begin{array}{c}1.83 \pm \\
0.14\end{array}$ & $\begin{array}{c}0.41 \pm \\
0.07\end{array}$ & $\begin{array}{c}0.50 \pm \\
0.44\end{array}$ & $1.87^{*}$ & 2.00 & $4.46^{*}$ \\
\hline
\end{tabular}

$* p<0.05$ indicates a statistically significance difference from the TGF- $\beta 1$-treated group. UT: untreated; TGF- $\beta$ :

TGF- $\beta 12$ ng/mL; SC: Salacia chinensis L. stem extract.

2.5. Salacia chinensis L. (SC) Stem Extract Ameliorates the Phosphorylations of SMAD2/3, ERK1/2, and p38 Induced by TGF- $\beta 1$

TGF- $\beta 1$ can stimulate the receptor and convey the signal transduction via several different cascades. SMAD2/3 and MAPKs are major responsible signal transduction pathways of TGF- $\beta 1$. We therefore evaluated whether SC stem extract exerts its antifibrotic ability through the suppression of these two pathways. We found that cells treated with TGF- $\beta 1$ showed an increase in SMAD2/3, ERK1/2 and p38 phosphorylation compared to those of untreated condition, as seen in Figure 6A-E. Interestingly, SC extract at $0.01,0.05$, and $0.1 \mathrm{mg} / \mathrm{mL}$ significantly reduced phosphorylation of SMAD2/3, ERK1/2, and p38, as seen in Figure 6A-E.

A
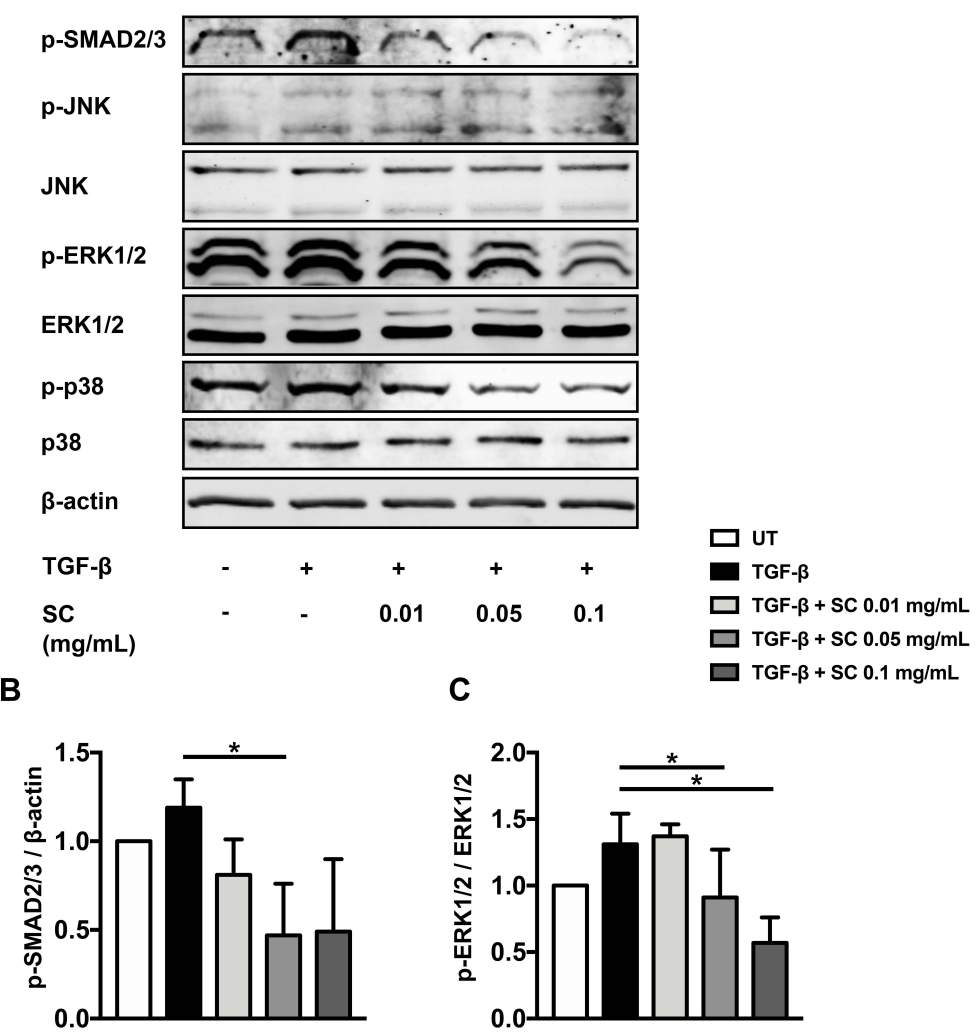

Figure 6. Cont. 
D

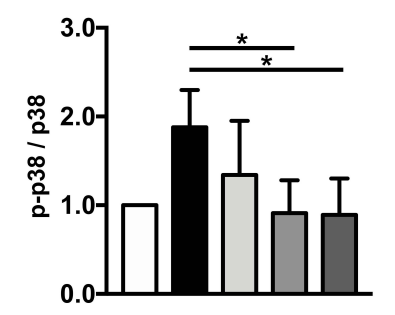

E

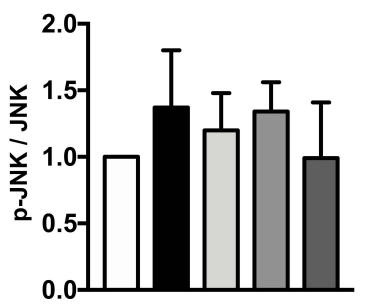

Figure 6. Effects of SC stem extract on phosphorylation of SMAD2/3, ERK1/2, p38, and JNK kinase. Western blot analysis of phosphorylated SMAD2/3, phosphorylated ERK1/2, ERK1/2, phosphorylated p38, p38, phosphorylated JNK, and JNK proteins are shown in (A). The bar graphs represent the relative expression of phosphorylated SMAD2/3 to $\beta$-actin (B), phosphorylated ERK1/2 to ERK1/2 (C), phosphorylated p38 to p38 (D), and phosphorylated JNK to JNK (E). UT: untreated; TGF- $\beta$ : TGF- $\beta 12 \mathrm{ng} / \mathrm{mL}$; SC: Salacia chinensis L. extract. ${ }^{*} p<0.05$ indicates statistical significance from TGF- $\beta 1$-treated group.

\section{Discussion}

Fibrosis and cirrhosis of the liver have become major causes of morbidity and mortality across the world $[27,28]$. Currently, there is no standard treatment for liver fibrosis. Liver transplant has shown improvement of both survival and quality of life in patients with cirrhosis, but this treatment is invasive, expensive, and cannot be performed for all fibrotic and cirrhosis patients [5].

Fortunately, a wide range of biological activities offered by natural products and herbal medicines has emerged as one of potential treatments for hepatic fibrosis [7]. Salacia chinensis L. has been incorporated into Thai folk medicine for the treatment of hepatic cirrhosis since 2007 [8]. Previous studies have demonstrated that lignans, eleutheroside E2, and $7 R$, $8 S$-dihydrodehyrodiconideryl alcohol $4-O-\beta-D$-glucopyranoside, which are constituents isolated from SC leaves by methanol extraction, exhibit hepatoprotective effects in primary cultured mouse hepatocytes [29]. However, the Thai traditional formulation for hepatic fibrosis treatment contains Salacia chinensis L. stem water extraction, in which gallic acid was found to be a main component. Moreover, the recent publication revealed the effects of gallic acid on hepatic fibrosis by increasing HSCs apoptosis and reducing hepatocyte oxidative stress [30]. These results suggest that the antifibrotic activities of Salacia chinensis L. stem water extract possibly come from gallic acid.

TGF- $\beta 1$ is a member of the TGF- $\beta$ superfamily, playing a critical role in the development of hepatic fibrosis [31]. TGF- $\beta$ activates the TGF- $\beta$ receptor [32] and relays signal transduction through phosphorylation of downstream effectors, such as SMAD2/3 [12,33], and we found that SC stem extract significantly inhibited phosphorylation of SMAD2/3 and reduced mRNA expression of TGF- $\beta 1$. These results suggest that the extract can inhibit the TGF- $\beta 1$ activation of the SMAD-dependent signal transduction pathway. It has been shown that ERK can also phosphorylate the linker regions of SMAD1 and SMAD2/3, and consequently inhibit ligand-induced nuclear translocation of SMADs, thereby promoting the TGF- $\beta$ antiproliferative response [34,35]. Similarly, JNK phosphorylates SMAD3 outside its SXS motif in response to mitogenic and stress signals, leading to enhanced activation and nuclear translocation of SMAD3 [36]. In addition, activation of MAPK kinase 1, which is an activator of JNK, ERK, and p38, results in phosphorylation and activation of SMAD2 [37]. Our data showed that even though cells were stimulated with TGF- $\beta 1$, the SC treatment could potently inhibit phosphorylation of members of the MAPK kinase pathway, including JNK, ERK, and p38. These results are promising for identifying possible mechanisms of action of Salacia chinensis L. in suppressing the production of fibrotic markers in response to TGF- $\beta 1$ activation.

MMP-2 activity and production were reduced in SC stem extract treated cells, while the activity and production of MMP-9 were increased in a concentration-dependent manner. These observations strongly suggest that the extract has the ability to suppress MMP-2, but induce MMP-9 expression and function. It is well known that at the early stage of hepatic fibrosis, the expression of MMP-2 is very 
high [38]. Therefore, agents proved to be potent inhibitors of MMP-2 may be beneficial for hepatic fibrosis treatment. SC extract has potential to be developed as an antifibrotic agent.

Besides metalloproteinases, other molecules are involved in ECM accumulation which is a common presentation of liver fibrosis $[1,16,17,39,40]$. TIMPs are a class of secreted enzymes that play a crucial role in deposition and breakdown of ECM [41,42]. TIMP-1 and TIMP-2 are known to be profibrotic factors in the liver [10,43]. It has been reported that liver-specific overexpression of TIMP-1 leads to more severe fibrosis without a significant effect on collagen synthesis [44]. The relationship of TIMP-1 and MMP-9 can be seen by the fact that TIMP-1 can inhibit MMP-9. Therefore, if TIMP-1 is inhibited, the level of MMP-9 activity is normally increased, and thus apoptosis is induced $[9,26]$. Consistent with the observation that the extract increased MMP-9 production and activity, it also significantly suppressed TIMP-1. In contrast to TIMP-1, TIMP-2 functions as both an MMP inhibitor and activator depending upon its level of production [45,46]. TIMP-2 can inhibit MMP-2 activity by blocking MMP-2 enzyme catalytic site [45]. However, if TIMP-2 is highly produced (like in the case of patients with liver fibrosis, where the level of serum MMP-2 is also high), it can bind to the $\mathrm{C}$ terminal region of newly synthesized MMP-2 being transported to the plasma membrane, where this dimer interacts with the membrane-type MMPs, which activates the activity of MMP-2 [7,45-48]. Our observation that SC stem extract could suppress TIMP-2 and MMP-2 production strongly suggests that the extract may be able to inhibit hepatic fibrogenesis at least in part through the suppression of MMP-2 activation due to the reduction of TIMP-2 level.

We are the first group to reveal the effects of SC stem extract on antifibrotic activities by modulating the fibrogenesis processes of HSCs from the gene through protein levels. The extract markedly attenuated TGF- $\beta 1$-stimulated HSC activation. Crucial molecular factors, including $\alpha$-SMA, COL1A1, TIMP-1, TIMP-2, MMP-2, and TGF- $\beta 1$ that normally contribute to fibrosis in HSCs were proved to be significantly reduced by the effect of the extract, whereas the extract tends to increase the production and activity of MMP-9. Our findings provide evidence that Salacia chinensis L. stem extract may have potential for development as an antihepatic fibrosis treatment in the future.

\section{Materials and Methods}

\subsection{Preparation and Characterization of SC Stem Extract}

The S. chinensis L.'s voucher specimen number, PBM 04927, was authenticated and deposited at the Faculty of Pharmacy, Mahidol University, Thailand. For preparing the extract, $60 \mathrm{~g}$ of dried SC stem was pulverized into a coarse powder and boiled with $600 \mathrm{~mL}$ of distilled water at $100{ }^{\circ} \mathrm{C}$ by reflux twice for $2 \mathrm{~h}$. The filtrate was evaporated and spray-dried at input temperature of $185^{\circ} \mathrm{C}$ (temperature of the heater) and then at an output temperature of $86^{\circ} \mathrm{C}$ (temperature of the extract). The extract was dark brown and dissolved freely in water.

Determination of phenolic content in the extract was determined by HPLC using a C18 column $(250 \mathrm{~mm} \times 4.6 \mathrm{~mm}, 5 \mu \mathrm{m})$. Gradient elution was performed using two solvents; A (1\% acetic acid in water) and B (100\% acetonitrile) for detection. Twenty microliters of the $10 \mathrm{mg}$ of SC stem extract was dissolved in $1 \mathrm{~mL}$ of $\mathrm{diH}_{2} \mathrm{O}$ and injected into the column with a flow rate $0.7 \mathrm{~mL} / \mathrm{min}$ and detection at $280 \mathrm{~nm}$. Peak area and retention time of the extract sample were determined in the comparison with standard curves of various concentration of standard chlorogenic acid, gallic acid, ferrulic acid, mangiferin, and vanillic acid.

\subsection{Cell Culture}

The human HSC cell line, LX-2, was obtained from Merck (Darmstadt, Germany). Cells were cultured in Dulbecco's modified Eagle's medium (DMEM; Gibco, Thermo Fisher Scientific, Waltham, MA, USA), supplemented with $2 \mathrm{mM} \mathrm{L-glutamine,} 2 \%$ fetal bovine serum (FBS; Capricorn Scientific, Ebbsdorfer Grund, Germany), $100 \mathrm{U} / \mathrm{mL}$ penicillin, and $100 \mu \mathrm{g} / \mathrm{mL}$ streptomycin (Gibco, Thermo Fisher Scientific, Waltham, MA, USA) and incubated at $37{ }^{\circ} \mathrm{C}$ in a $5 \% \mathrm{CO}_{2}$ humidified 
incubator. Cells were subcultured at approximately $80 \%$ confluent ( $3-4$ days after plating cells) by $0.25 \%$ trypsin-EDTA (Gibco, Thermo Fisher Scientific, Waltham, MA, USA).

\subsection{Cell Viability Assay}

LX-2 cells were plated in a 96-well plate at a density of $5 \times 10^{4}$ cells/well and cultured in DMEM supplemented with $2 \%$ FBS for $24 \mathrm{~h}$. After that, SC extract $(0-0.1 \mathrm{mg} / \mathrm{mL})$ was added into each well and incubated for $48 \mathrm{~h}$. Cell viability was measured by MTT assay. In short, $20 \mathrm{mg} / \mathrm{mL}$ of MTT in PBS was added directly to each well and incubated at $37^{\circ} \mathrm{C}, 5 \% \mathrm{CO}_{2}$ for $1-4 \mathrm{~h}$. Then, the purple formazan was solubilized by DMSO. The color intensity was measured at $570 \mathrm{~nm}$ by a microplate reader (M965, Metertech Inc., Taiwan). The experiment was performed in triplicate.

\subsection{Cell Migration Assay}

To determine the cell migration ability of LX-2 cells with and without SC extract. LX-2 cells were seeded and cultured as described in Section 4.3. After the scratch wound was made, cells were treated with SC extracts for $48 \mathrm{~h}$. The migration of cells was determined at different time points $(0$, 24 , and $48 \mathrm{~h}$ ). The closing of scratched wounds was considered to be the completion of the migration process. The migrated areas were analyzed and determined using Image software.

\subsection{Immunofluorescence Study}

To determine the level of collagen I and $\alpha$-SMA protein production, immunofluorescence study was performed. Briefly, the cells were stimulated with $2 \mathrm{ng} / \mathrm{mL}$ of TGF- $\beta 1$ for $24 \mathrm{~h}$ at $37^{\circ} \mathrm{C} 5 \% \mathrm{CO}_{2}$ and then treated with SC extract with the presence of $2 \mathrm{ng} / \mathrm{mL}$ of TGF- $\beta 1$ for $48 \mathrm{~h}$. After treatment, cells were fixed with $4 \%$ paraformaldehyde in PBS for $15 \mathrm{~min}$ and washed with PBS. Next, cells were permeabilized by $0.3 \%$ Triton-X 100 in PBS for 5 min and washed again with PBS. Then, cells were incubated with blocking buffer (1\% BSA in PBS) for $1 \mathrm{~h}$ and with 1:100 of primary antibodies (collagen-1 and $\alpha$-SMA) overnight at $4{ }^{\circ} \mathrm{C}$ in a moist chamber. An antimouse antibody conjugated with Alexa- 488 (Thermo Fisher Scientific, Waltham, MA, USA) with the presence of $5 \mu \mathrm{g} / \mathrm{mL}$ Hoechst 33342 (for nuclei staining) (Thermo Fisher Scientific, Waltham, MA, USA) at 1:400 were used to incubate $1 \mathrm{~h}$ at room temperature (RT) in the dark. After washing, cells were mounted and then visualized under a fluorescence microscopy (microscope, AX70 Olympus R, Japan).

\subsection{Western Blot Analysis}

Cells were treated and incubated as described in Section 4.5. After that, cells were lysed with $1 \times$ reducing Laemmli buffer, collected and heated at $95^{\circ} \mathrm{C}$ for $5 \mathrm{~min}$, then separated by $10 \%$ SDS-PAGE and transferred to PVDF membranes. The membranes were blocked with $5 \%$ nonfat milk in PBS containing $0.05 \%$ tween-20 for $1 \mathrm{~h}$ at RT and then incubated with 1:1000 of primary antibodies at $4{ }^{\circ} \mathrm{C}$ overnight. Anti- $\alpha$-SMA antibody was obtained from Sigma-Aldrich (Singapore). Anti p-SMAD2/3, p-p38, pJNK, pERK1/2, p38, JNK, ERK1/2, COL1A1, MMP-2, MMP-9, TIMP-1, and TIMP-2 antibodies were purchased from Cell Signaling Technology (USA). The day after primary antibody incubation, membranes were incubated with 1:5000 secondary antibodies (IRDye ${ }^{\circledR} 800 \mathrm{cw}$ antimouse or IRDye ${ }^{\circledR}$ 680RD antirabbit IgG). The protein immunoreactive bands were visualized by LI-COR odyssey CLx western blotting detector (LI-COR, Lincoln, NE, USA) and quantitated using Image J software.

\subsection{Gelatin Zymography Assay}

The activity of MMP was evaluated by gelatin zymography assay. Cells were treated and incubated as described in Section 4.5. Then, the supernatants were collected and electrophoresed on gelatin-containing 10\% SDS-polyacrylamide gels in a cold running condition. The gels were washed twice in $2.5 \%$ TritonX-100 and incubated for 30 min followed by brief rinsing with $10 \mathrm{mM}$ Tris, $\mathrm{pH} 8.0$. The gels were incubated overnight at $37^{\circ} \mathrm{C}$ in gelatinase buffer $(50 \mathrm{mM}$, Tris $\mathrm{HCL}$, and $10 \mathrm{mM} \mathrm{CaCl}$ 
$\mathrm{pH}$ 8). Then, the gels were stained with $0.5 \%(\mathrm{w} / \mathrm{v})$ Coomassie blue R250 in $50 \%$ methanol and $10 \%$ glacial acetic acid for $30 \mathrm{~min}$, and destained. The clear zones of gelatin digestion indicate MMP-2 and MMP-9 activity. After scanning the gel, the area of clear zones was analyzed by ImageJ software.

\subsection{Quantitative Real-Time PCR}

The expression of $\alpha$-SMA, COL1A1, MMP-2, MMP-9, TIMP-1, and TGF- $\beta 1$ genes was detected by quantitative real-time PCR. Briefly, cells were treated and incubated as described in Section 4.5. Total RNA was extracted using an RNA extraction kit (Qiagen, Hilden, Germany). Real-time PCR reaction was performed using ReverTra Ace ${ }^{\circledR}$ qPCR RT master mix with gDNA Remover protocol. The thermocycler setting was $2 \mathrm{~min}$ at $95^{\circ} \mathrm{C}$ for polymerase activation, $15 \mathrm{~s}$ at $95^{\circ} \mathrm{C}, 15 \mathrm{~s}$ at $58^{\circ} \mathrm{C}$, and $1 \mathrm{~min}$ at $72{ }^{\circ} \mathrm{C}$ for 40 cycles of amplification on the PCRmax Eco 48 real time PCR system (Staffordshire, ST15 OSA, UK). GAPDH was used as reference mRNA. Samples were analyzed in triplicate for each set of primers. The oligonucleotide PCR primers used in real-time PCR (Thermo Fisher Scientific, Waltham, MA, USA) are shown in Table 2:

Table 2. Primers for qRT-PCR.

\begin{tabular}{ccc}
\hline Genes & Forward Primer (F) & Reverse Primer (R) \\
\hline$\alpha$-SMA & $5^{\prime}$-CGCATCCTCATCCTCCCT-3' & $5^{\prime}$-GGCCGTGATCTCCTTCTG-3' \\
COL1A1 & $5^{\prime}$-GTCGAGGGCCAAGACGAAG-3' & $5^{\prime}$-CAGATCACGTCATCGCACAAC-3' \\
$M M P-2$ & $5^{\prime}$-ACATCAAGGGCATTCAGGAG-3' & $5^{\prime}$-GCCTCCGTATACCGCATCAAT-3' \\
$M M P-9$ & $5^{\prime}$-CCCGGAGTGAGTTGAACCA-3' & $5^{\prime}$-GGATTTACATGGCACTGCCA-3' \\
TIMP-1 & $5^{\prime}$-CTTCTGCAATTCCGACCTCGT-3' & $5^{\prime}$-CCCTAAGGCTTGGAACCCTTT-3' \\
TGF- $\beta 1$ & $5^{\prime}$-GGCCAGATCCTGTCCAAGC-3' & $5^{\prime}$-GTGGGTTTCCACCATTAGCAC-3' \\
GAPDH & $5^{\prime}$-ATGGGGAAGGTGAAGGTCG-3' & $5^{\prime}$-GGGGTCATTGATGGCAACAATA-3' \\
\hline
\end{tabular}

\subsection{Data and Statistical Analysis}

Data were expressed as mean \pm standard deviation. One-way ANOVA followed by least-significant difference (LSD) post-hoc analysis was used to determine the difference between groups. $p$ values less than 0.05 were considered statistically significant.

Supplementary Materials: Supplementary materials can be found at http://www.mdpi.com/1422-0067/20/24/ 6314/s1.

Author Contributions: S.P. supervised and designed the study. M.P. performed the most of experiment. M.N.T. performed quantitative real-time PCR. P.P. and P.B. characterized the extract. S.P., W.N. and S.J. interpreted the results and generated the figures and tables. M.P., S.P. and W.N. wrote the manuscript. S.J. and W.N. suggested and reviewed the manuscript. N.S. and S.S. prepared and provided the extract.

Funding: This research was supported by grants from Faculty of Medicine, Chiang Mai University (SP), Thailand Research Fund (MRG6180078: SP) and partially supported by Chiang Mai University.

Acknowledgments: We thank Sathit Monkaew for assistance with laboratory support.

Conflicts of Interest: The authors declare no conflict of interest. The funders had no role in the project design, data collection, interpretation, or decision to publish.

\section{Abbreviations}

$\begin{array}{ll}\text { ALP } & \text { alkaline phosphatase } \\ \text { ALT } & \text { valanine aminotransferase } \\ \text { AST } & \text { aspartate aminotransferase } \\ \text { COL1A1 } & \text { collagen type I alpha 1 chain } \\ \text { ECM } & \text { extracellular matrix } \\ \text { ERK } & \text { extracellular signal- regulated kinase }\end{array}$




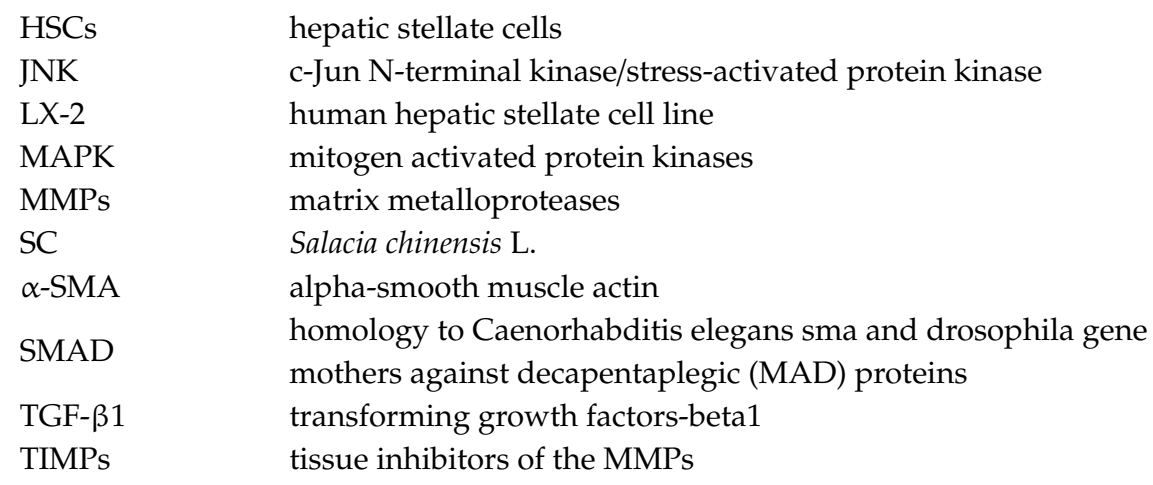

\section{References}

1. Hernandez-gea, V.; Friedman, S.L. Pathogenesis of Liver Fibrosis. Ann. Rev. Pathol. Mech. Dis. 2011, 6, 425-456. [CrossRef] [PubMed]

2. Xu, J.; Liu, X.; Koyama, Y.; Wang, P.; Lan, T.; Kim, I.G.; Kim, I.H.; Ma, H.Y.; Kisseleva, T. The types of hepatic myofibroblasts contributing to liver fibrosis of different etiologies. Front. Pharmacol. 2014, 5, 167. [CrossRef] [PubMed]

3. Xu, R.; Zhang, Z.; Wang, F.S. Liver fibrosis: Mechanisms of immune-mediated liver injury. Cell. Mol. Immunol. 2012, 9, 296-301. [CrossRef] [PubMed]

4. Hinz, B.; Phan, S.H.; Thannickal, V.J.; Galli, A.; Bochaton-Piallat, M.L.; Gabbiani, G. The myofibroblast: One function, multiple origins. Am. J. Pathol. 2007, 170, 1807-1816. [CrossRef] [PubMed]

5. Mormone, E.; George, J.; Nieto, N. Molecular pathogenesis of hepatic fibrosis and current therapeutic approaches. Chem. Biol. Interact. 2011, 193, 225-231. [CrossRef] [PubMed]

6. Trautwein, C.; Friedman, S.L.; Schuppan, D.; Pinzani, M. Hepatic fibrosis: Concept to treatment. J. Hepatol. 2015, 62, S15-S24. [CrossRef] [PubMed]

7. Elpek, G.O. Cellular and molecular mechanisms in the pathogenesis of liver fibrosis: An update. World J. Gastroenterol. 2014, 20, 7260-7276. [CrossRef]

8. Giannandrea, M.; Parks, W.C. Diverse functions of matrix metalloproteinases during fibrosis. Dis. Model. Mech. 2014, 7, 193-203. [CrossRef]

9. Duarte, S.; Baber, J.; Fujii, T.; Coito, A.J. Matrix metalloproteinases in liver injury, repair and fibrosis. Matrix Biol. 2015, 44, 147-156. [CrossRef]

10. Arpino, V.; Brock, M.; Gill, S.E. The role of TIMPs in regulation of extracellular matrix proteolysis. Matrix Biol. 2015, 44, 247-254. [CrossRef]

11. Park, S.A.; Kim, M.J.; Park, S.Y.; Kim, J.S.; Lim, W.; Nam, J.S.; Yhong Sheen, Y. TIMP-1 mediates TGF- $\beta$-dependent crosstalk between hepatic stellate and cancer cells via FAK signaling. Sci. Rep. 2015, 5, 16492. [CrossRef] [PubMed]

12. Biernacka, A.; Dobaczewski, M.; Frangogiannis, N.G. TGF- $\beta$ signaling in fibrosis. Growth Factors 2011, 29 , 196-202. [CrossRef] [PubMed]

13. Meng, X.; Nikolic-Paterson, D.J.; Lan, H.Y. TGF- $\beta$ : The master regulator of fibrosis. Nat. Rev. Nephrol. 2016, 12, 325-338. [CrossRef] [PubMed]

14. Liu, Y.; Wang, Z.; Kwong, S.Q.; Lui, E.L.H.; Friedman, S.L.; Li, F.R.; Lam, R.W.C.; Zhang, G.C.; Zhang, H.; Ye, T. Inhibition of PDGF, TGF- $\beta$, and Abl signaling and reduction of liver fibrosis by the small molecule Bcr-Abl tyrosine kinase antagonist Nilotinib. J. Hepatol. 2011, 55, 612-625. [CrossRef]

15. Zhang, Y.E. Non-Smad pathways in TGF- $\beta$ signaling. Cell Res. 2009, 19, 128-139. [CrossRef]

16. Bataller, R.; Brenner, D. Liver fibrosis. J. Clin. Investig. 2005, 115, 209-218. [CrossRef]

17. Schuppan, D.; Ashfaq-Khan, M.; Yang, A.T.; Kim, Y.O. Liver fibrosis: Direct antifibrotic agents and targeted therapies. Matrix Biol. 2018, 68, 435-451. [CrossRef]

18. Koyama, Y.; Xu, J.; Liu, X.; Brenner, D.A. New Developments on the Treatment of Liver Fibrosis. Dig. Dis. 2016, 34, 589-596. [CrossRef]

19. Chavan, J.J.; Jagtap, U.B.; Gaikwad, N.B.; Dixit, G.B.; Bapat, V.A. Total phenolics, flavonoids and antioxidant activity of Saptarangi (Salacia chinensis L.) fruit pulp. J. Plant Biochem. Biotechnol. 2013, 22, 409-413. [CrossRef] 
20. Chavan, J.J.; Ghadage, D.M.; Bhoite, A.S.; Umdale, S.D. Micropropagation, molecular profiling and RP-HPLC determination of mangiferin across various regeneration stages of Saptarangi (Salacia chinensis L.). Ind. Crops Prod. 2015, 76, 1123-1132. [CrossRef]

21. Ghadage, D.M.; Kshirsagar, P.R.; Pai, S.R.; Chavan, J.J. Extraction efficiency, phytochemical profiles and antioxidative properties of different parts of Saptarangi (Salacia chinensis L.)-An important underutilized plant. Biochem. Biophys. Rep. 2017, 12, 79-90. [CrossRef] [PubMed]

22. Tran, T.M.; Nguyen, T.H.A.; Vu, D.T.; Tran, V.S. Study on chemical constituents of Salacia chinensis L., collected in Thua Thien Hue. Tap Chi Hoa Hoc 2008, 46, 47-51.

23. Morikawa, T.; Akaki, J.; Ninomiya, K.; Kinouchi, E.; Tanabe, G.; Pongpiriyadacha, Y.; Yoshikawa, M.; Muraoka, O. Salacinol and related analogs: New leads for type 2 diabetes therapeutic candidates from the Thai traditional natural medicine Salacia chinensis. Nutrients 2015, 7, 1480-1493. [CrossRef] [PubMed]

24. Yoshikawa, M.; Shimoda, H.; Nishida, N.; Takada, M.; Matsuda, H. Salacia reticulata and Its Polyphenolic Constituents with Lipase Inhibitory and Lipolytic Activities Have Mild Antiobesity Effects in Rats. J. Nutr. 2002, 132, 1819-1824. [CrossRef]

25. Friedman, L.G.; Qureshi, Y.H.; Yu, W.H. Promoting Autophagic Clearance: Viable Therapeutic Targets in Alzheimer's Disease. Neurotherapeutics 2015, 12, 94-108. [CrossRef]

26. Duarte, S.; Hamada, T.; Kuriyama, N.; Busuttil, R.W.; Coito, A.J. TIMP-1 deficiency leads to lethal partial hepatic ischemia and reperfusion injury. Hepatology 2012, 56, 1074-1085. [CrossRef]

27. Lozano, R.; Naghavi, M.; Foreman, K.; Lim, S.; Shibuya, K.; Aboyans, V.; Abraham, J.; Adair, T.; Aggarwal, R.; Ahn, S.Y.; et al. Global and regional mortality from 235 causes of death for 20 age groups in 1990 and 2010: A systematic analysis for the Global Burden of Disease Study 2010. Lancet 2012, 380, 2095-2128. [CrossRef]

28. Wang, F.S.; Fan, J.G.; Zhang, Z.; Gao, B.; Wang, H.Y. The global burden of liver disease: The major impact of China. Hepatology 2014, 60, 2099-2108. [CrossRef]

29. Nakamura, S.; Zhang, Y.; Matsuda, H.; Ninomiya, K.; Muraoka, O.; Yoshikawa, M. Chemical structures and hepatoprotective effects of constituents from the leaves of Salacia chinensis. Chem. Pharm. Bull. 2011, 59, 1020-1028. [CrossRef]

30. El-Lakkany, N.M.; El-Maadawy, W.H.; Seif el-Din, S.H.; Saleh, S.; Safar, M.M.; Ezzat, S.M.; Mohamed, S.H.; Botros, S.S.; Demerdash, Z.; Hammam, O.A. Antifibrotic effects of gallic acid on hepatic stellate cells: In vitro and in vivo mechanistic study. J. Tradit. Complement. Med. 2019, 9, 45-53. [CrossRef]

31. Bi, W.-R.; Yang, C.-Q.; Shi, Q. Transforming growth factor- $\beta 1$ induced epithelial-mesenchymal transition in hepatic fibrosis. Hepatogastroenterology 2012, 59, 1960-1963. [CrossRef] [PubMed]

32. Feng, X.-H.; Derynck, R. Specificity and Versatility in Tgf-B Signaling Through Smads. Annu. Rev. Cell Dev. Biol. 2005, 21, 659-693. [CrossRef] [PubMed]

33. Verrecchia, F.; Mauviel, A. Transforming growth factor-beta and fibrosis. World J. Gastroenterol. 2007, 13, 3056-3062. [CrossRef] [PubMed]

34. Pera, E.M.; Ikeda, A.; Eivers, E.; De Robertis, E.M. Integration of IGF, FGF, and anti-BMP signals via Smad1 phosphorylation in neural induction. Genes Dev. 2003, 17, 3023-3028. [CrossRef] [PubMed]

35. Kretzschmar, M.; Doody, J.; Massagué, J. Opposing BMP and EGF signalling pathways converge on the TGF- $\beta$ family mediator Smad1. Nature 1997, 389, 618-622. [CrossRef] [PubMed]

36. Engel, M.E.; McDonnell, M.A.; Law, B.K.; Moses, H.L. Interdependent SMAD and JNK signaling in transforming growth factor-beta-mediated transcription. J. Biol. Chem. 1999, 274, 37413-37420. [CrossRef]

37. De Caestecker, M.P.; Parks, W.T.; Frank, C.J.; Castagnino, P.; Bottaro, D.P.; Roberts, A.B.; Lechleider, R.J. Smad2 transduces common signals from receptor serine-threonine and tyrosine kinases Smad2 transduces common signals from receptor serine-threonine and tyrosine kinases. Genes Dev. 1998, 12, 1587-1592. [CrossRef]

38. Préaux, A.M.; Mallat, A.; Nhieu, J.T.; D’Ortho, M.P.; Hembry, R.M.; Mavier, P. Matrix metalloproteinase-2 activation in human hepatic fibrosis regulation by cell-matrix interactions. Hepatology 1999, 30, 944-950. [CrossRef]

39. Henderson, N.C.; Iredale, J.P. Liver fibrosis: Cellular mechanisms of progression and resolution. Clin. Sci. 2007, 112, 265-280. [CrossRef]

40. Lee, U.E.; Friedman, S.L. Mechanisms of hepatic fibrogenesis. Best Pract. Res. Clin. Gastroenterol. 2011, 25, 195-206. [CrossRef] 
41. Visse, R.; Nagase, H. Matrix metalloproteinases and tissue inhibitors of metalloproteinases: Structure, function, and biochemistry. Circ. Res. 2003, 92, 827-839. [CrossRef] [PubMed]

42. Brew, K.; Dinakarpandian, D.; Nagase, H. Tissue inhibitors of metalloproteinases: Evolution, structure and function. Biochim. Biophys. Acta Protein Struct. Mol. Enzymol. 2000, 1477, 267-283. [CrossRef]

43. Thiele, N.D.; Wirth, J.W.; Steins, D.; Koop, A.C.; Ittrich, H.; Lohse, A.W.; Kluwe, J. TIMP-1 is upregulated, but not essential in hepatic fibrogenesis and carcinogenesis in mice. Sci. Rep. 2017, 7, 714. [CrossRef] [PubMed]

44. Yoshiji, H.; Kuriyama, S.; Miyamoto, Y.; Thorgeirsson, U.; Gomez, D.; Kawata, M.; Yoshii, J.; Ikenaka, Y.; Noguchi, R.; Tsujinoue, H.; et al. Tissue inhibitor of metalloproteinases-1 promotes liver fibrosis development in a transgenic mouse model. Hepatology 2000, 32, 1248-1254. [CrossRef] [PubMed]

45. Arthur, M.J.P.; Iredale, J.P.; Mann, D.A. Tissue Inhibitors of Metalloproteinases: Role in Liver Fibrosis and Alcoholic Liver Disease. Alcohol. Clin. Exp. Res. 1999, 23, 940-943. [CrossRef] [PubMed]

46. Arthur, M. Fibrogenesis II. Metalloproteases and their Inhibitors in liver fibrosis. Am. J. Physiol. Gastrointest. Liver Physiol. 2000, 279, G245-G249. [CrossRef]

47. Murawaki, Y.; Yamada, S.; Ikuta, Y.; Kawasaki, H. Clinical usefulness of serum matrix metalloproteinase-2 concentration in patients with chronic viral liver disease. J. Hepatol. 1999, 30, 1090-1098. [CrossRef]

48. Prystupa, A.; Boguszewska-Czubara, A.; Bojarska-Junak, A.; Torun-Jurkowska, A.; Roliński, J.; Załuska, W. Activity of MMP-2, MMP-8 and MMP-9 in serum as a marker of progression of alcoholic liver disease in people from Lublin region, eastern Poland. Ann. Agric. Environ. Med. 2015, 22, 325-328. [CrossRef]

(C) 2019 by the authors. Licensee MDPI, Basel, Switzerland. This article is an open access article distributed under the terms and conditions of the Creative Commons Attribution (CC BY) license (http://creativecommons.org/licenses/by/4.0/). 